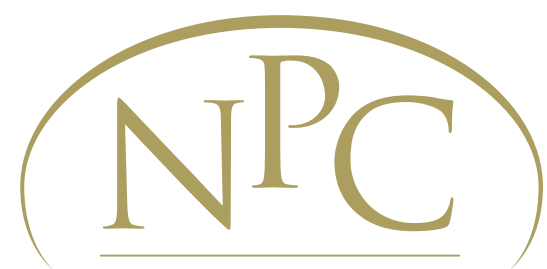

NATIONAL POVERTY

CENTER

National Poverty Center Working Paper Series

$\# 11-30$

October 2011

\title{
Do Single Mothers in the United States use the Earned Income Tax Credit to Reduce Unsecured Debt?
}

\author{
H. Luke Shaefer, Xiaoqing Song, and Trina R. Williams Shanks, \\ University of Michigan
}

This paper is available online at the National Poverty Center Working Paper Series index at: http://www.npc.umich.edu/publications/working_papers/

Any opinions, findings, conclusions, or recommendations expressed in this material are those of the author(s) and do not necessarily reflect the view of the National Poverty Center or any sponsoring agency. 


\title{
Do Single Mothers in the United States use the Earned Income Tax Credit to Reduce
}

\section{Unsecured Debt?}

\author{
October 13, 2011 \\ H. Luke Shaefer* \\ Assistant Professor \\ University of Michigan School of Social Work \\ 1080 South University Ave \\ Ann Arbor, MI 48109 \\ 1shaefer@umich.edu \\ 734.936 .5065 \\ Xiaoqing Song \\ Ph.D. Candidate \\ University of Michigan Department of Economics \\ Trina R. Williams Shanks \\ Associate Professor \\ University of Michigan School of Social Work
}

\begin{abstract}
The Earned Income Tax Credit (EITC) is a refundable credit for low-income workers that is mainly targeted at families with children. This study uses the Survey of Income and Program Participation's (SIPP) topical modules on Assets \& Liabilities to examine the effects of EITC expansions during the early 1990s on the unsecured debt of the households of single mothers. We use two difference-in-differences comparisons over the study period 1988 to 1999, first comparing single mothers to single childless women, and then comparing single mothers with two or more children to single mothers with exactly one child. In both cases we find that the EITC expansions are associated with a relative decline in the unsecured debt of affected households of single mothers. This suggests that single mothers may have used part of their EITC to limit the growth of their unsecured debt during this period.
\end{abstract}

Key Words: Earned Income Tax Credit; Single Mothers; Unsecured Debt

This work has been supported by a grant from the National Poverty Center at the University of Michigan, which is supported by award \#1 U01AE000002-02 from the U.S. Department of Health and Human Services, office of the Assistant Secretary for Planning and Evaluation. Any opinions expressed are those of the authors alone and should not be construed as representing the opinions or policy of any agency or the Federal Government. We thank Jennifer Romich and Sheldon Danziger for reviewing earlier versions of this manuscript. 


\section{Introduction}

The Earned Income Tax Credit (EITC) is a refundable tax credit for low-income workers. It is mainly targeted toward low-income families with children with incomes up to about twice the poverty line. To beneficiaries, the credit represents a large, annual, tax-free income transfer. Only a few studies, though, have examined how beneficiaries allocate their EITC. Most utilize evidence from non-representative surveys of recipients (Smeeding, Phillips \& O’Conner, 2000; Rhine, Su, Osaki \& Lee, 2005; Spader, Ratcliffe \& Stegman, 2005; Mendenhall, Edin, Crowley, Sykes, Tach, King \& Kriz, 2010; Romich \& Weisner, 2000). A few analyze nationally representative data to compare groups that include likely beneficiaries, such as single mothers, to groups that are unlikely to benefit, such as single childless women (Meyer \& Sullivan, 2004; Barrow \& McGranahan, 2000).

We extend this line of research by using the Survey of Income and Program Participation's (SIPP) topical modules on Assets \& Liabilities to examine associations between the major EITC expansions of the 1990s and the unsecured debt of households of working-age single mothers, during the years 1988-1999. We utilize a difference-in-differences approach, with two separate comparisons that have been used extensively in the literature to examine the effects of the EITC. First we compare the unsecured debt of single mothers to single childless women, over time. Then we compare the unsecured debt of single mothers with two or more children (who received a larger EITC increase during our study period) to those with exactly one child. In both cases, we find evidence that the EITC expansions are associated with a relative decline in unsecured debt among households of single mothers during this period. This suggests that single mothers may have used some portion of their EITC to limit the growth of unsecured debt, bucking the national trend of rising unsecured debt during our study time period. 


\section{Background \& Literature Review}

At nearly $\$ 58$ billion in total credits for tax year 2009 (serving 26 million tax filing units), the EITC is the federal government's most expensive means-tested income maintenance program. In addition, 22 states plus the District of Columbia have their own EITCs. Available evidence suggests that most EITC eligible taxpayers receive the credit (Scholz, 1994; Currie, 2006). Since 1984, EITC benefits have not been included in eligibility calculations for other public welfare programs. Thus, unlike most sources of income, increases in the EITC do not trigger reductions in other public benefits beyond what is related to increased labor force participation induced by the EITC.

The credit amount increases as labor market earnings increase, up to a plateau, where it reaches its maximum level. The credit remains at its maximum amount until it begins to decrease in the phase-out range, finally falling to zero at an annual income level around 200 percent of poverty. A number of studies have considered the EITC's effects on labor force participation (Dahl, DeLeire \& Schwabish, 2009; Ellwood, 2000; Meyer \& Rosenbaum, 2001; Hotz \& Scholz, 2003; Eissa \& Liebman, 1996). These studies generally find that the EITC has a positive effect on the labor force participation of single mothers (at the extensive margin-results for the intensive margin are ambiguous), and a negative effect on the labor force participation of lowwage working married women (Hoynes, 2008).

A few studies examine how families allocate dollars from their EITC refund. Smeeding and colleagues surveyed 650 EITC beneficiaries who used a nonprofit tax preparation service in the Chicago region in 1998. They found that 70 percent of EITC recipients planned to use part of their refund for "economic- and social-mobility" purposes, such as saving (33 percent) or purchasing a car (19 percent), while 69 percent planned to use part for "making-ends-meet" uses, 
such as rent or utility bills, and making other purchases. The top priority for about half the sample was to pay bills, while only 12 percent listed saving as their top priority. Mendenhall et al. (2010) interviewed 194 EITC recipients from Illinois and Massachusetts, at two points: tax filing in 2007, and six months later. Among all recipients, about half of the total refund went toward current consumption, and about 24 percent went toward paying back debt, overdue bills, or prepaying bills. At the 6-month mark, 6.7 percent of recipient's refunds remained in savings. These findings are similar to those from a survey of IRS Volunteer Tax Assistance (VITA) Program clients in North Carolina (Spader et al., 2005).

An ethnographic study in Wisconsin found that beneficiaries tended to use the EITC to make large purchases or increase consumption (Romich \& Weisner, 2000). Barrow and McGranahan (2000) analyzed Consumer Expenditure Survey (CES) data from 1982-1996 and found that the EITC was associated with increased consumer spending, most obviously on durable goods, during February_-when most recipients receive their EITC benefit. Meyer and Sullivan (2004) also use CES and find that, between 1984 and 2000, the overall consumption of households headed by single mothers grew relative to households of single childless women and married mothers, which they attribute to changes in the EITC, as well as welfare reform and other changes to the tax code affecting this population.

In sum, the previous studies offer strong evidence that recipients spend a portion of their EITC benefits on current consumption (Mendenhall et al. 2010; Meyer \& Sullivan, 2004; Barrow \& McGranahan 2000; Romich \& Wiesner, 2000, Smeeding et al., 2000). In this study, we explored the extent to which EITC recipients use their refunds for unsecured debt reduction. Like Meyer and Sullivan, we focus on single mothers, the primary beneficiaries of the EITC, and we focus on the 12-year period 1988 through 1999, which straddles a significant expansionary 
period for the EITC. This period also coincided with a substantial rise in unsecured debt. Credit card debt, for example, grew by 315 percent between 1989 and 2006, to $\$ 876$ billion (Garcia, 2007). Growth in access to credit cards and credit card debt has been greatest among poor households (Sullivan, 2008).

We hypothesized that the major EITC expansions of the early 1990s were associated with a reduction in the unsecured debt of households with single mothers. While the EITC may have an ambiguous effect on secured debt—by promoting vehicle or home purchase — the evidence suggests that the effect on unsecured debt should be unambiguous: single mothers may use their tax refund to pay down existing unsecured debt, such as back bills. Or, they may use their refund to avoid new debt by making large purchases with cash instead of credit (Mendenhall et al. 2010).

\section{Data and Method}

We utilize the Survey of Income and Program Participation (SIPP), a nationally representative sample of the civilian non-institutionalized population in the United States. During each panel, interviews are conducted every four months for each intervening month, gathering data on demographics, welfare, family income and composition, labor force participation, and program participation. We merge data from the monthly survey with responses from Assets \& Liabilities topical modules in the 1987 SIPP panel (wave 4); the 1990 panel (wave 4); the 1991 panel (wave 7); the1992 panel (wave 4); the 1993 panel (wave 7); and the 1996 panel (waves 3, 6,9 and 12).

This SIPP topical module has detailed asset and liability questions, including actual monetary values. The SIPP's relatively large sample size allows researchers to study specific sub-populations. Comparison studies find that the SIPP does a good job of capturing the wealth 
of low-income households, relative to other major surveys (Czajka et. al, 2003; Ratcliffe et. al, 2008). ${ }^{1}$ All asset and liability estimates are reported in real 2005 dollars. We follow Meyer and Rosembaum (2001) and adjust dollar values using the monthly personal consumption expenditure index and state cost-of-living differences index developed by the National Research Council (1995). We cluster all standard errors by state to account for the SIPP's stratified survey design. The SIPP's measure of unsecured debt is broad, including debt from credit cards and store bills, unsecured loans obtained through a bank or credit union, and other debts including medical bills not covered by insurance, money owed to private individuals, and other debts not covered. $^{2}$

Our study population is single adult mothers (ages 19-55) with minor children, because they receive roughly 60 percent of total EITC credit dollars (Meyer \& Sullivan, 2004). We examine two difference-in-differences comparisons. We first compare single childless women to single mothers because single mothers were differentially affected by the EITC expansions of the early 1990s, while the two groups faced similar labor market conditions. ${ }^{3}$ We then compare single mothers with exactly one child to single mothers with two or more children, who received a substantially larger targeted increase in their EITC benefit during our study period. ${ }^{4}$ In all analyses, we compare the outcomes of the experimental group to those of the control group

\footnotetext{
${ }^{1}$ The only potential problems that could affect quality are attrition across waves and item non-response on particular asset and liability items. Missing values are imputed within bracketed categories, but these methods are less accurate when variables have high non-response rates.

${ }^{2}$ The SIPP Asset and Liabilities survey instrument can be found at www.census.gov/sipp/top_mod/1996/quests/wave3/assetlia.html

${ }^{3}$ This comparison is used in numerous difference-in-differences studies of the labor market participation effects of the EITC, see Meyer \& Rosenbaum, 2001, and was used in a difference-in-differences study of the impact of the EITC and other public program and tax code changes on consumption by Meyer \& Sullivan, 2004. It should be noted that the EITC first offered a credit to low-wage workers with no children in tax year 1994, which likely would have benefited single childless women. However, this credit remains quite small, relative to what was received by families with children. By the end of our study period (1999), filers with no children could receive a maximum credit of about $\$ 400$, while the maximum for filers with one child was about $\$ 2,700$ and $\$ 4,450$ for filers with two or more children (all adjusted to 2005 dollars).

${ }^{4}$ This comparison is used in a difference-in-differences study of labor market earnings effects of the EITC by Dahl et al., 2009 .
} 
across the study time period. This is done in an effort to control for changing macroeconomic and other conditions that might drive outcomes during the period, which would have likely affected the experimental and control groups similarly.

A limitation of the SIPP Assets \& Liabilities topical module is that variables are collected at the household level. Therefore, for single mothers who cohabit - even if they are the household head - the assets and liabilities information may include data from other adult household respondents as well. We think it is important to examine results for all single women — even those who are not household heads — because research emphasizes the high prevalence of co-habitation for single mothers (Folk, 1996; Bumpass \& Raley, 1995). Thus, restricting our results only to household heads may risk biasing our results, as household heads may be different from other single mothers in non-representative ways. Thus, in all of our analyses, we consider results for all single women, as well as household heads only. In sensitivity analyses, we attempt to control for the presence of other adults in the household.

We focus our investigation around the exogenous changes to the EITC that are straddled by the twelve-year study period 1988-1999. This study period closely mirrors the ones used by Dahl et al., 2009 and Meyer \& Sullivan, 2004. Figure 1 shows the maximum EITC credit in real 2005 dollars for the period 1985-2006. The credit for 1990 (realized in 1991) was $\$ 1,424$. By 1995 (realized in 1996), this had grown to \$2,683 for families with one child, and nearly tripled for families with 2 or more children to $\$ 3,985$. Our analyses are conducted on data from the SIPP Assets \& Liabilities topical modules on estimates of household assets and liabilities for 1988, 
1991, 1993, 1995, 1996, 1997 and 1999. ${ }^{5}$ This includes multiple data points before and after the EITC expansions under study were implemented.

This analysis faces concerns about the potential confounding effects of the 1996 welfare reform that ended the entitlement for cash welfare in the U.S. However, the majority of states did not implement their TANF program until 1997, while the EITC expansions under study went into effect earlier (Crouse, 1999). Thus, we would expect for the effect of the expanded EITC to first appear in 1996, after the large expansions of the EITC credit would have been realized by families, but before welfare reform was fully implemented. Welfare waiver programs implemented prior to 1997 varied in size and character, with many limited to certain counties. Thus, we think it is unlikely that these programs, on the whole, could lead to clear changes in the assets and liabilities levels of our study population, on a national level. Still, in our multivariate models we control for the possible confounding effects of welfare reform in two ways. First, we control for the presence of waiver programs and the implementation of state-level TANF programs by state-month-year. More importantly, our second difference-in-differences comparison of single mothers with exactly one child to those with multiple children should mitigate this concern, as these two groups were similarly affected by the 1996 welfare reform, but differentially affected by the EITC expansions under study.

Relative to single childless women, we hypothesize that the unsecured debt of single mothers will fall over the period 1988-1999. Further, the EITC expanded specifically for families with $2+$ children at the end of our period, 1994-1996. Thus, we would further expect the unsecured debt of single mothers with two or more children to fall in the final years of our analysis, relative to single mothers with one child. We further hypothesize that, during the early

\footnotetext{
${ }^{5}$ The Assets and Liabilities topical module was also administered in 1998. However, the point estimates for our study populations for 1998 were associated with extremely large standard errors, making them essentially meaningless. Thus, we dropped data from this year.
} 
years of our study period, the unsecured debt of single mothers with two or more children should increase relative to that of single mothers with exactly one child, and then decrease in 1996 and later. This is because during the earlier years of our study period, these groups received similarly sized credit amounts, which would have been a larger proportion of the average budget of a single mother family with one child. However, when the credit was increased specifically for families with multiple children, this should have led to a relative improvement of the position of single mothers with multiple children.

For multivariate analyses, we utilize the standard difference-in-differences approach, with two separate models.

$$
\begin{aligned}
& U D_{i, t}=X \beta_{i, t}+\text { pyear }_{i, t}+\text { rsinglemother }_{i, t}+\lambda\left(\text { singlemother }_{i, t} * \text { year }_{i, t}\right)+\varepsilon_{i, t}
\end{aligned}
$$

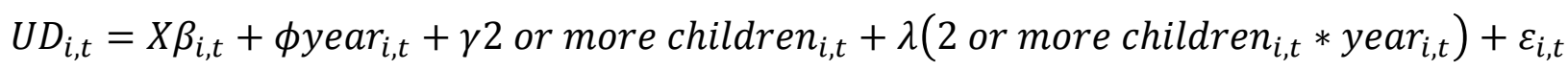

In both equations, $U D$ represents the unsecured debt of individual $i$ at time t. $X$ is a vector of individual and environmental characteristics that include race and ethnicity, age (in dummy categories for age groups $<25,25-34,35-44$, and $45-55$ ), education (college graduate, 0,1 ), whether a state welfare waiver program was in effect $(0,1)$, whether a state TANF program was in effect $(0,1)$, and region dummies. Year indicates the year of the observation.

For both models, the sample is restricted to the experimental group and the control group. In equation 1, the experimental group is single mothers, while the control group is single childless women. The singlemother term is an indicator that the respondent is a single mother. The interaction term singlemother*year is the difference-in-differences estimator. With these interactions included, the stand-alone singlemother indicator comes to represent the difference in unsecured debt between single mothers and single childless women in the base year of 1988. The 
interaction terms then represent the change in the differential between these two groups in the non-base years of the study.

Equation 2 follows the same method as equation 1, but is restricted to single mothers. The experimental group is those with 2 or more children, while the comparison group is made up of those with exactly 1 child. In this case, we use 1995 as the base year.

Our multivariate models take three forms. We first estimate ordinary least squares models using the outcome of unsecured debt in real dollars (adjusted for inflation). We use real dollars because it is the most direct way to measure the impact of the EITC. ${ }^{6}$ Because of concerns that outliers may be driving our results, we also utilize two additional specifications: 1) quantile regression at the 75 percentile, which will be unmoved by extreme values at either end of the distribution of the outcome (Meyer \& Sullivan, 2004); and 2) models in which the dependent variable is converted using the inverse hyperbolic sine (IHS) transformation. IHS can be used to reduce the influence of outliers, and can be interpreted similarly to models using the more common natural log transformation (in which point estimates indicate percentage change rather than change in real dollars). IHS offers an added benefit of allowing the dependent variable to take positive, negative, and zero values (Burbidge, Magee \& Robb, 1988). ${ }^{7,8}$ All regressions are

\footnotetext{
${ }^{6}$ We hypothesize that the EITC will have a direct impact over time on the difference in the real dollar value between the mean unsecured debt of the experimental group and the control group. The impact of the EITC on the ratio between these two measures will be less straighforward. Take the following example: let's assume that prior to the EITC expansions, single mother households have an average unsecured debt of $\$ 3,500$ and single childless women have an unsecured debt of $\$ 4,000$ ( $\$ 500$ difference, ratio $88 \%$ ). In the first year after the EITC is implemented, the value for single mothers falls to $\$ 3250$, while the value for single childless women increases to $\$ 4,500(\$ 1,250$ difference, $72 \%$ ). But in the second year after implementation, the unsecured debt of single mothers is $\$ 4,250$, while the value is $\$ 5,500$ for single childless women. In this case, the difference-in-difference estimate in real dollars is the same $(500-\$ 1250=\$ 750)$, but the estimate in terms of the ratio narrows $(.88-.77)$.

${ }^{7}$ The IHS transformation function is $g\left(y_{t}, \theta\right)=\log \left(\theta y_{t}+\left(\theta^{2} y_{t}^{2}+1\right)^{1 / 2}\right) / \theta=\sinh ^{-1}\left(\theta y_{t}\right) / \theta$. In STATA, the estimated function of IHS transformation is $\operatorname{asinh}(\mathrm{x})=\ln \left\{\mathrm{x}+\operatorname{sqrt}\left(\mathrm{x}^{*} \mathrm{x}+1\right)\right\}$. That is, theta is equal to 1 .

${ }^{8} \mathrm{We}$ also examined the density of values for unsecured debt for the two groups, using the kernel density estimator. The densities for the two groups appear to have very similar shapes and ranges of values over the years. Zero values account for a relatively big proportion of the observations, so using IHS allows us to include all the values of the dependent variable, while also reducing the effects of the outliers.
} 
run unweighted, although they were also run with weights, and the results did not change substantively.

\section{Descriptive Results}

Our pooled sample yields 49,251 observations of single women between the ages of 19 and 55 for the period 1988 to 1999. Among them, 16,425 are single mothers and 32,826 single childless women. ${ }^{9}$ Table 1 presents descriptive characteristics of the sample at our starting (1988) and ending points (1999). Single mothers are far more likely to be black or of Hispanic origin than single childless women. Single mothers are also less likely to have a college degree than single childless women. Both groups become less likely to be non-Hispanic white over the study period. The most noticeable change between the two periods is the growth in the proportion of single mothers who are working, from 57.9 in 1988 to 74.5 percent in 1999. This change was driven in part by the EITC expansions under study, along with other factors (Meyer and Rosenbaum, 2001). The labor force participation of single childless women also increases over the two periods, but less dramatically, from 72.9 to 76.3 percent.

Table 2 reports the mean unsecured debt levels of households with single women by year for the study period 1988-1999, with four panels reporting on (1) all single women, (2) loweducated single women with a high school diploma or less, (3) household heads, and (4) a final panel restricted to single mothers by number of children. ${ }^{10}$

Estimates from the first three panels generally suggest that the unsecured debt of single mothers fell relative to single childless women following the expansions of the EITC. Examining panel 1, in 1988, the mean unsecured debt of single mothers was $\$ 1,658$ less than and about 65

\footnotetext{
${ }^{9}$ Note that 1998 is not included, see footnote 4.

${ }^{10} \mathrm{We}$ do not report median levels of unsecured debt because only about half of households of single mothers report any unsecured debt, thus making medians uninformative. In multivariate analyses we take this into account by estimating both a quantile regression model at the $75^{\text {th }}$ percentile, and a model in which the dependent variable is transformed using IHS.
} 
percent of the mean level of unsecured debt held by households of single childless women. By 1996 , the difference between these two means had risen to $\$ 3,883$ less, and the ratio between the two groups was 50 percent. It should be noted that the unsecured debt values move around considerably from year-to-year. Still, there appears to have been a marked shift in the unsecured debt of single mothers relative to single childless women. In the first three years of our study period, which might be considered "pre-EITC expansion," the average difference in mean unsecured debt between single mothers and single childless women was $-\$ 1,944$, and the average ratio between the means of these two groups was 62 percent. If we consider the final three years of the study period as "post-expansion" years, the average difference between the means of these two groups was $-\$ 3,377$ and that average ratio was 55 percent.

The next panel restricts the sample to low-educated women, and the results are perhaps even more striking. From 1988 to 1993, the unsecured debt of low-educated single mothers appears to have been converging with that of low-educated single childless women, so that by 1993 , the difference between the mean values for these two groups was only $-\$ 249$ and the ratio between them was 92 percent. In the post expansion years, however, the unsecured debt of single mothers relative to single childless women falls considerably, never going below $-\$ 1,900$, and the ratio between the means of the two groups ranges from 40 to 58 percent.

Turning to household heads in the bottom left hand panel, while interpretation of the results is less straightforward, they still appear to follow the same pattern. In the pre-recession years, the average difference between the mean level of unsecured debt of single mothers and single childless women was $\$-1,343$, and the ratio between the means of the two groups was 67 percent. In comparison, in the post-recession years, the mean difference was $-\$ 2,842$ and the average ratio was 56 percent. 
It is worth noting that the relative trends observed in table 2 are a result of rising unsecured debt among single childless women, and not falling unsecured debt among single mothers. Single childless women saw their household unsecured debt grow from $\$ 4,738$ in 1988 to $\$ 7,852$ in 1999 (a 66 percent increase). This trend appears somewhat larger than, although consistent with, the overall sample of working-age adults in the U.S., whose household unsecured debt we estimate went from $\$ 5,883$ in 1988 to $\$ 8,573$ in 1999 (a 46 percent increase). In contrast, households with single mothers saw their unsecured debt increase much less, from $\$ 3,080$ to $\$ 4,181$ (a 26 percent increase). So, if the EITC is having an effect, it is to decrease the growth of the unsecured debt of households with single mothers over time from what it would have been otherwise.

The bottom right-hand panel of table 2 reports on the final descriptive test of our hypothesis. As figure 1 shows, the maximum credit available to single mothers with 1 child and those with 2 or more children diverge in the final years of our study period, as the credit for families with multiple children was expanded. Given the timing of this expansion, we believe that if the expanded credit caused a differential change in unsecured debt between these two groups of single mothers, this might become evident in 1996 or later. Estimates in table 2 follow the hypothesized pattern: between 1988 and 1995, single mothers with 2 or more children appear to lose ground in terms of unsecured debt load relative to single mothers with 1 child, so that by 1995 , the difference between the means of the two groups is only $-\$ 323$. However, between 1996 and 1999, single mothers with $2+$ children saw their household unsecured debt level off, while single mothers with 1 child — for whom the EITC credit stagnated between 1994 and 1996 - saw their household unsecured debt increase from $\$ 3,428$ in 1995 to $\$ 4,922$ in 1999. 
On the whole, the evidence from table 2 is consistent with the hypothesis that the EITC expansions of the early 1990s had a negative effect on the unsecured debt of single mothers. However, these estimates do not control for competing factors that may be impacting the unsecured debt of single women.

\section{Multivariate Results}

In table 3, column 1 reports on a linear probability model in which $U D$ is 1 if the individual lived in a household with unsecured debt $>0$. The results show that the probability of carrying any unsecured debt for single mothers remained fairly stable relative to single childless women, going from a statistically significant 7.1 percentage points less likely in 1988 to 9.7 percentage points less likely in 1996, and then back to 7.2 percentage points in 1999 . None of the difference-in-differences interaction terms are statistically significantly different from the reference year. This suggests that any relative decline in unsecured debt across this period is being driven mainly by a relative reduction of debt among those that carry it, and not a change in the relative probability of carrying $>0$ unsecured debt.

The next three columns report on OLS models in which the dependent variable is unsecured debt in real dollars for (2) all single women; (3) household heads; and (4) loweducated women. According to estimates from our baseline model presented in column 2, in 1988 households with single mothers carried a statistically insignificant \$165 dollars less in unsecured debt than households of single childless women, after controlling for other factors. In the pre-EITC years, there was no statistically significant change in this differential. In 1996, however, households with single mothers carried $\$ 2,796$ less in unsecured debt relative to single childless women, and the change from the differential between these two groups in the base year was statistically significant at the $\mathrm{p}<.01$ level. The differential between single mothers and single 
childless women remained large and statistically significantly different from 1988 for the final two years of the study period. In terms of the unsecured debt of single mothers relative to single childless women, there was a substantial and statistically significant change during the postEITC expansion years.

Single mother household heads followed a similar pattern. In 1988, they carried a statistically insignificant $\$ 58$ dollars more in unsecured debt than single childless women, and this differential did not change to a statistically significant degree in 1991, 1993, or 1995. In 1996 , however, this differential changed by a statistically significant $-\$ 3,132$, and remained at large and statistically significantly different from the base year for the rest of the study period. It is worth noting that the point estimate for 1996 is quite a bit larger than those for 1997 and 1999. Still, even an average of the three post-EITC expansion years, compared to an average of the three pre-expansion years, suggests a marked shift in the unsecured debt of single mothers relative to single childless women. Column 4 restricts the sample to low-educated women with a high school degree or less. During the period 1988 to 1995, the unsecured debt of low-educated single mothers converged with that of their childless counterparts. This trend reversed course in 1996-1999. However, the change in this differential is only statistically significantly different from the base year in 1997.

Column 5 of table 3 reports on a model using quantile regression at the $75^{\text {th }}$ percentile. This is to ensure that the results in the OLS models are not being driven by a few extreme values. Our quantile regression results are robust and in fact more stable than our OLS model. At the $75^{\text {th }}$ percentile, household with single mothers saw their unsecured debt go from $\$ 483$ less than the households of single childless women in 1988 to $\$ 1,589$ less in 1995 , then remained virtually 
unchanged at about $-\$ 2,500$ for the remainder of the study period. The post-EITC expansion point estimates are highly statistically significant.

Column 6 of table 3 reports on a final model in which unsecured debt is transformed using IHS. ${ }^{11}$ Based on the point estimates of IHS regressions and the calculated average values of real unsecured debt of all single women (reported in table A.1), we can see that the baseline trends still hold. Households with single mothers carried a statistically significant $\$ 2,585$ less in unsecured debt in 1988 than households with single childless women and this differential remained substantively similar and not statistically significantly different during the pre-EITC years. There was a statistically significantly large increase in the differential in 1995 and 1996, and the differential remained elevated in 1997 and 1999, although not statistically significantly different from 1988 in these years.

Table 4 reports on results from our second difference-in-differences comparison. As previously mentioned, our hypothesis would predict that single mothers with 2 or more children would reduce their unsecured debt relative to single mothers with just one child during the years following the EITC increase targeted at families with multiple children. Our OLS and quantile regression results are consistent with this hypothesis. For the OLS model in column 1, our reference year is 1995 , the calendar year before single mothers with multiple children would have received the expanded credit. From 1988 to 1995, the difference in unsecured debt carried by single mothers with 2 or more children converged with that of single mothers with exactly 1

\footnotetext{
${ }^{11}$ The IHS regression equation when $\theta=1$ can be written as $\log \left(y+\sqrt{y^{2}+1}\right)=\beta x+\varepsilon$, and $\hat{\beta}=\partial \log \left(y+\sqrt{y^{2}+1}\right) / \partial x=\left(1 / \sqrt{y^{2}+1}\right) \partial y / \partial x$, and therefore, $\partial y / \partial x=$ $\sqrt{y^{2}+1} * \hat{\beta}$. So the estimated impact of whether being a single mom in year $t$ on the IHS transformed real unsecured debt is the IHS point estimate times the square root of the squared mean unsecured debt plus one. In this sense, the advantage of the IHS regression is that it can reduce the effects of the outliers like the natural log transformation while also allowing for the inclusion of zero values and an interpretation of the point estimates that is similar to the real value regressions since the estimates take into account the average values of the dependent variables.
} 
child, so that in 1995 , the difference between the two groups was a statistically insignificant \$181. As with the models in table 3, however, this trend reverses during the post-EITC expansion years. Relative to single mothers with just one child, the unsecured debt of single mothers with multiple children falls $\$ 1,649$ between 1995 and 1996, and remains at a similar level in 1997 (the point estimate in 1999 is statistically insignificant). The quantile regression results (reported in column 2) tell a similar story. The difference in the unsecured debt of single mothers with one child and those with multiple children at the $75^{\text {th }}$ percentile does not change to a statistically significant degree between 1988 and 1995, but does change in the post-expansion years, remaining statistically significantly and substantively lower than the base year through 1999. Finally, column 3 reports on a model in which unsecured debt has been transformed using IHS. The results are inconclusive because the point estimates are not statistically significant. However, they do seem to indicate that the unsecured debt of single mothers with multiple children was increasing in the pre-EITC expansion years relative to single mothers with 1 child, and decreased in 2 of the 3 post-EITC expansion years.

\section{Sensitivity Analyses}

We undertook numerous sensitivity tests of the robustness of our findings. If the effects we have identified are related to the EITC expansions, we would expect them to be concentrated among working women. In an attempt to test this, we restricted our sample only to women who were working in the month of observation. (This is not a perfect test, since EITC benefits are based on annual earnings from a calendar year prior to the observation month). We found that the effect we identified was concentrated among working women. The difference-in-differences point estimates from a model of non-workers were statistically insignificant. We also wanted to test the possibility that changing rates of post-secondary school enrollment and student debt may 
be driving our results. To test this, we added an indicator of current school enrollment, and our results remained substantively similar. In an attempt to control for co-habitation, we added a variable for the number of adults in the household, and one for the number of single mothers in the household. As might be expected, the number of adults in the household variable appears to be important, with each additional adult being associated with an increase in household unsecured debt. Still, interpretation of the year*single mother terms remains similar to models presented in table 3 .

Finally, we wanted to examine whether the relationships we have identified were consistent across the various types of unsecured debt. While the data do not allow us to run our multivariate models with these sub-categories as outcomes because of sample size limitations, we replicated our descriptive estimates from table 2 for all single women for the three subcategories 1) credit card debt; 2) unsecured bank loans; and 3) all other unsecured debts (medical, bank bills, loans owed to private individuals, and other unsecured debts). It appears as though the relationships we have identified in the preceding analyses are concentrated in the last two sub-categories, and do not appear for credit card debt.

\section{Study Limitations}

One concern is that our results are largely based on the changes in estimates that occurred between SIPP panels with different samples. While our findings from two different differencein-differences tests fit with our hypothesis, it is also possible that the results are being driven by changes in the sample structure, or data collection procedures. However, the Asset and Liabilities topical module questions remained consistent across the panels, and previous research has pooled data from these topical modules from the 1996 panel with earlier panels (Sullivan, 2006). This concern also highlights the strength of the differences-in-differences approach. For changes 
in the survey between panels to affect our results, it would have had to impact single childless women differentially from single mothers. Otherwise, the comparative method neutralizes this concern. Further, while we cannot completely rule out the possibility that our findings are an artifact of the data, it is worth noting again that evaluations have found that the SIPP does a comparatively good job of capturing the wealth of low-income households (Czajka et. al, 2003; Ratcliffe et. al, 2008). Also, our findings are robust across a number of tests including all single women, low-skilled single women, working single women, and single mothers by number of children.

Perhaps our results are a result of biased unsecured debt estimates for single childless women in the later years of the sample, specifically for the jump in unsecured debt of single childless women between 1995 and 1996. Because of this concern, we compared the estimates for single childless women to single childless men, and found that the change between the periods for these two groups were quite similar (means for single childless women are \$5486 in 1991; \$5421 in 1995; and \$7778 in 1996. Means for single childless men are \$5683 in 1991; $\$ 5215$ in 1995; and \$7568 in 1996.) In table 2, we find an immense jump in unsecured debt for low-educated single childless women between 1995 and 1996, which is of concern. However, the standard error for the 1996 mean for this smaller sub-group is quite large $(1,860)$, making the estimate inefficient (and somewhat larger than the jump experienced by low-educated single childless men). This is why we focus our main analyses on the larger population of single women, and control for education in our main multivariate models.

A final concern is that changes in other policies during our study period may have differentially affected single mothers relative to single childless women, and may be driving our results. We have tried to mitigate this concern by utilizing two difference-in-differences tests, 
one in particular that compares single mothers by number of children. We also include controls for the implementation of a welfare waiver program and a TANF program in our multivariate models. Still, this is a limitation of our work. We focus our analysis on the EITC because there is a theoretical and empirical basis for the hypothesis that it might be negatively associated with unsecured debt.

\section{Discussion}

The early 1990s was a period of substantial growth in unsecured debt across the population as a whole, and especially among poor households. It was also a period of substantial expansion of the Earned Income Tax Credit, which has grown into the major incomemaintenance program in the U.S. targeted toward low-income working families with children. During the period 1988 to 1999, we find that households with single mothers bucked the national trend of rising unsecured debt. We believe our results support the findings of existing nonrepresentative household surveys, which suggest that EITC recipients use a sizable portion of their EITC to pay down unsecured debt, which includes credit card debt, past-due bills, debt to pay day loan providers, and other debts. This was during a period in which single mothers were 1) increasing their labor market activity, 2) in which unsecured debt was becoming more easily accessible to low-educated individuals, and 3) the consumption of single mothers was increasing, which would have likely led to upward pressure on unsecured debt.

If the EITC does in fact allow single mothers with children to pay down their unsecured debt—or allows them to avoid added debt—we believe it is making a significant contribution in the financial stability of these households. Today, in the midst of the economic crisis and increased insecurity in both employment and financial markets, the importance to families of 
stabilizing one's finances by reducing debt or increasing savings has become even more apparent.

Existing research suggests that recipients view their EITC differently from their labor market earnings, indeed, they appear to prefer the lump-sum delivery which makes the program unique. They appear to like the process of allocating their dollars in ways that they feel maximizes the utility of their families (Romich \& Weisner, 2000; Mendenhall et al., 2010). If policymakers are interested in encouraging asset building among recipients, they will have to explore initiatives that raise the benefits of savings for these families - making it more attractive to allocate a larger amount to savings — or raise the costs of borrowing unsecured debt. Indeed, it likely makes the most economic sense for poor families to allocate proportionately more to unsecured debt reduction, debt which may be borrowed at a high interest rate, before shoring up household savings, which may yield a smaller return. This may be the best decision in terms of the financial stability and possible future asset development of these families. Still, it is hard to claim that paying down debt is a form of asset building. Thus, while we believe our results lend support to findings that households with single mothers allocate a significant portion of the EITC benefits to paying down debt, they lend further doubt to the notion that the EITC is serving as a wealth generator. 


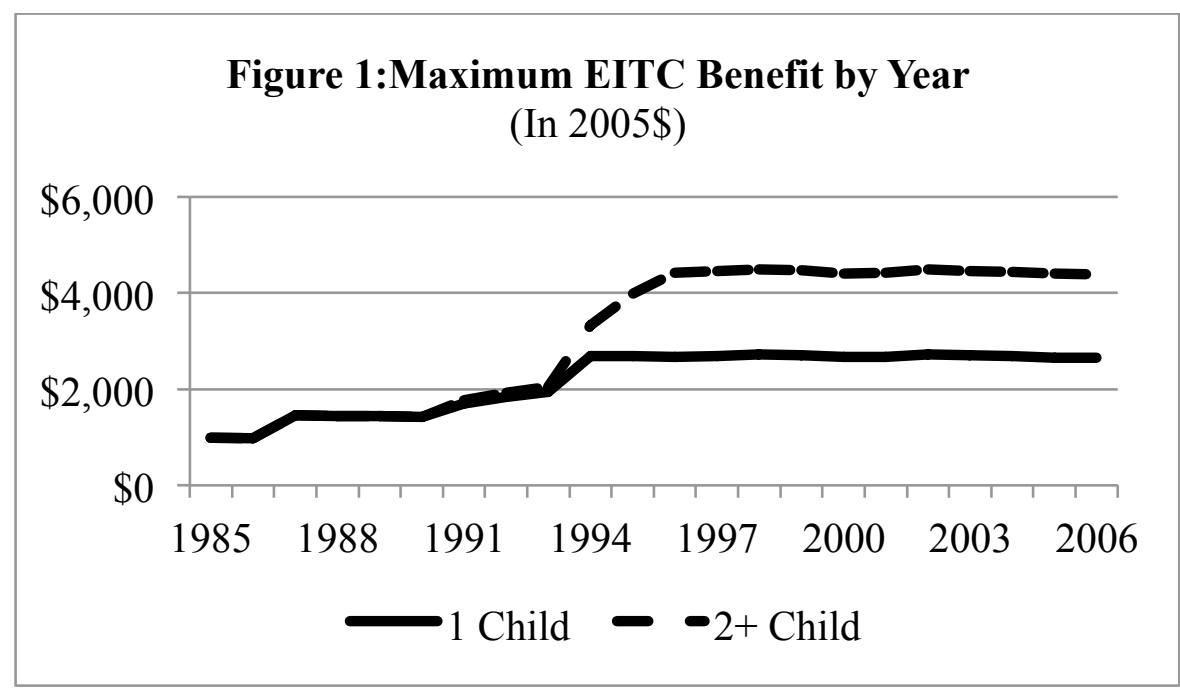

Source: Tax Policy Center

http://www.taxpolicycenter.org/taxfacts/displayafact.cfm?Docid=36 
Table 1

Characteristics of Single Women Ages 19-55, 1988 \& 1999

Means

\begin{tabular}{|c|c|c|c|c|}
\hline & \multicolumn{2}{|c|}{ Single Mothers } & \multicolumn{2}{|c|}{$\begin{array}{l}\text { Single Women, No } \\
\text { Children }\end{array}$} \\
\hline & 1988 & 1999 & 1988 & 1999 \\
\hline \multicolumn{5}{|l|}{ Race and Ethnicity } \\
\hline White, Non-Hispanic & 56.9 & 52.1 & 77.9 & 70.8 \\
\hline Black & 30.6 & 30.7 & 13.7 & 16.5 \\
\hline Amer Indian, Eskimo or Aleut & 1.0 & 2.0 & 0.5 & 1.5 \\
\hline Asian or Pacific Islander & 1.0 & 2.3 & 3.0 & 3.7 \\
\hline Hispanic Origin & 12.8 & 14.7 & 6.1 & 8.4 \\
\hline Age & 33.7 & 34.8 & 31.0 & 34.4 \\
\hline Employed & 57.9 & 74.5 & 72.9 & 76.3 \\
\hline \multicolumn{5}{|l|}{ Education } \\
\hline$<$ High School Degree & 28.5 & 23.2 & 14.0 & 14.6 \\
\hline High School Graduate Only & 38.6 & 35.9 & 28.2 & 27.1 \\
\hline College Graduate & 21.1 & 21.6 & 33.9 & 32.3 \\
\hline Family Income (\% FPL) & 177 & 194 & 325 & 360 \\
\hline $\mathrm{N}$ & & & & \\
\hline
\end{tabular}

Source: Authors' calculations from a pooled sample of the SIPP Assets and Liabilities topical modules. All estimates are weighted. 
Table 2

Total Household Unsecured Debt of Single Women Age 19-55, 1988-1999

Means 2005\$

\begin{tabular}{|c|c|c|c|c|c|c|}
\hline \multirow[t]{2}{*}{ Year } & Mothers & $\begin{array}{l}\text { Childless } \\
\text { Women }\end{array}$ & $\begin{array}{l}(1)-(2) \\
(1) /(2)\end{array}$ & Mothers & $\begin{array}{l}\text { Childless } \\
\text { Women }\end{array}$ & $\begin{array}{l}(4)-(5) \\
(4) /(5)\end{array}$ \\
\hline & $(1)$ & $(2)$ & $(3)$ & $(4)$ & $(5)$ & $(6)$ \\
\hline \multicolumn{4}{|c|}{ All Single Women } & \multicolumn{3}{|c|}{ Low-educated Single Women } \\
\hline 1988 & $\begin{array}{c}\$ 3,080 \\
(334)\end{array}$ & $\begin{array}{c}\$ 4,738 \\
(305)\end{array}$ & $\begin{array}{c}-\$ 1,658 \\
65 \%\end{array}$ & $\begin{array}{c}\$ 1,929 \\
(322)\end{array}$ & $\begin{array}{c}\$ 3,218 \\
(236)\end{array}$ & $\begin{array}{c}-\$ 1,289 \\
60 \%\end{array}$ \\
\hline 1991 & $\begin{array}{l}3,168 \\
(276)\end{array}$ & $\begin{array}{l}5,486 \\
(282)\end{array}$ & $\begin{array}{c}-2,318 \\
58 \%\end{array}$ & $\begin{array}{l}2,130 \\
(221)\end{array}$ & $\begin{array}{l}3,261 \\
(261)\end{array}$ & $\begin{array}{c}-1,131 \\
65 \%\end{array}$ \\
\hline 1993 & $\begin{array}{l}3,164 \\
(428)\end{array}$ & $\begin{array}{l}5,020 \\
(271)\end{array}$ & $\begin{array}{c}-1,856 \\
63 \%\end{array}$ & $\begin{array}{l}2,741 \\
(650)\end{array}$ & $\begin{array}{l}2,990 \\
(163)\end{array}$ & $\begin{array}{l}-249 \\
92 \%\end{array}$ \\
\hline 1995 & $\begin{array}{l}3,263 \\
(338)\end{array}$ & $\begin{array}{l}5,421 \\
(317)\end{array}$ & $\begin{array}{c}-2,158 \\
60 \%\end{array}$ & $\begin{array}{l}1,742 \\
(162)\end{array}$ & $\begin{array}{l}3,320 \\
(348)\end{array}$ & $\begin{array}{c}-1,578 \\
52 \%\end{array}$ \\
\hline 1996 & $\begin{array}{l}3,895 \\
(187)\end{array}$ & $\begin{array}{l}7,778 \\
(724)\end{array}$ & $\begin{array}{c}-3,883 \\
50 \%\end{array}$ & $\begin{array}{l}2,560 \\
(254)\end{array}$ & $\begin{array}{c}6,436 \\
(1,860)\end{array}$ & $\begin{array}{c}-3,876 \\
40 \%\end{array}$ \\
\hline 1997 & $\begin{array}{l}4,326 \\
(295)\end{array}$ & $\begin{array}{l}6,903 \\
(282)\end{array}$ & $\begin{array}{c}-2,577 \\
63 \%\end{array}$ & $\begin{array}{l}2,599 \\
(220)\end{array}$ & $\begin{array}{l}4,509 \\
(278)\end{array}$ & $\begin{array}{c}-1,910 \\
58 \%\end{array}$ \\
\hline 1999 & $\begin{array}{l}4,181 \\
(288)\end{array}$ & $\begin{array}{l}7,852 \\
(510)\end{array}$ & $\begin{array}{c}-3,671 \\
53 \%\end{array}$ & $\begin{array}{l}2,728 \\
(249)\end{array}$ & $\begin{array}{l}4,716 \\
(247)\end{array}$ & $\begin{array}{c}-1,988 \\
58 \%\end{array}$ \\
\hline \multicolumn{4}{|c|}{ Household Heads } & \multicolumn{3}{|c|}{ Single Mothers by Number of Children } \\
\hline & Mothers & $\begin{array}{l}\text { Childless } \\
\text { Women }\end{array}$ & $\begin{array}{l}(7)-(8) \\
(7) /(8) \\
\end{array}$ & $2+$ Children & 1 Child & $\begin{array}{r}(10)-(11) \\
(10) /(11) \\
\end{array}$ \\
\hline & $(7)$ & $(8)$ & $(9)$ & $(10)$ & $(11)$ & $(12)$ \\
\hline 1988 & $\begin{array}{l}2,747 \\
(330)\end{array}$ & $\begin{array}{l}3,682 \\
(251)\end{array}$ & $\begin{array}{c}-\$ 935 \\
74 \%\end{array}$ & $\begin{array}{l}2,283 \\
(383)\end{array}$ & $\begin{array}{l}3,764 \\
(431)\end{array}$ & $\begin{array}{c}-\$ 1,481 \\
61 \%\end{array}$ \\
\hline 1991 & $\begin{array}{l}2,796 \\
(300)\end{array}$ & $\begin{array}{l}4,443 \\
(247)\end{array}$ & $\begin{array}{c}-1,647 \\
63 \%\end{array}$ & $\begin{array}{l}2,710 \\
(291)\end{array}$ & $\begin{array}{l}3,585 \\
(440)\end{array}$ & $\begin{array}{l}-875 \\
76 \%\end{array}$ \\
\hline 1993 & $\begin{array}{l}2,516 \\
(316)\end{array}$ & $\begin{array}{l}3,957 \\
(227)\end{array}$ & $\begin{array}{c}-1,441 \\
64 \%\end{array}$ & $\begin{array}{l}2,589 \\
(255)\end{array}$ & $\begin{array}{l}3,708 \\
(858)\end{array}$ & $\begin{array}{c}-1,119 \\
70 \%\end{array}$ \\
\hline 1995 & $\begin{array}{l}3,379 \\
(417)\end{array}$ & $\begin{array}{l}4,518 \\
(324)\end{array}$ & $\begin{array}{c}-1,139 \\
75 \%\end{array}$ & $\begin{array}{l}3,105 \\
(493)\end{array}$ & $\begin{array}{l}3,428 \\
(370)\end{array}$ & $\begin{array}{l}-323 \\
91 \%\end{array}$ \\
\hline 1996 & $\begin{array}{l}3,208 \\
(167)\end{array}$ & $\begin{array}{c}7,180 \\
(1,264)\end{array}$ & $\begin{array}{c}-3,972 \\
45 \%\end{array}$ & $\begin{array}{l}3,046 \\
(274)\end{array}$ & $\begin{array}{l}4,671 \\
(233)\end{array}$ & $\begin{array}{c}-1,625 \\
65 \%\end{array}$ \\
\hline 1997 & $\begin{array}{l}3,749 \\
(358)\end{array}$ & $\begin{array}{l}5,833 \\
(282)\end{array}$ & $\begin{array}{c}-2,084 \\
64 \%\end{array}$ & $\begin{array}{l}3,173 \\
(310)\end{array}$ & $\begin{array}{l}5,383 \\
(453)\end{array}$ & $\begin{array}{c}-2,210 \\
58 \%\end{array}$ \\
\hline 1999 & $\begin{array}{l}3,621 \\
(337)\end{array}$ & $\begin{array}{l}6,093 \\
(294)\end{array}$ & $\begin{array}{c}2,472 \\
59 \%\end{array}$ & $\begin{array}{l}3,384 \\
(444)\end{array}$ & $\begin{array}{l}4,922 \\
(327)\end{array}$ & $\begin{array}{c}-1,538 \\
69 \%\end{array}$ \\
\hline
\end{tabular}

Source: Authors' calculations from a pooled sample of the SIPP Assets and Liabilities topical modules. All estimates are weighted. Standard errors are clustered by state. 
Table 3

Multivariate Results: Household Unsecured Debt of Single Women, Ages 19-55, 1988-1999 (2005\$)

\begin{tabular}{|c|c|c|c|c|c|c|}
\hline & $\begin{array}{l}\text { LP Model } \\
\quad(0,1) \\
\end{array}$ & $\begin{array}{l}\text { All Single } \\
\text { Women }\end{array}$ & $\begin{array}{c}\text { Household } \\
\text { Heads }\end{array}$ & $\begin{array}{c}\text { Low-Educated } \\
\text { Women }\end{array}$ & $\begin{array}{c}\text { Quant Reg } \\
75^{\text {th }} \text { Percentile }\end{array}$ & IHS \\
\hline Variable & $(1)$ & $(2)$ & (3) & (4) & $(5)$ & (6) \\
\hline \multirow[t]{2}{*}{ Single mother } & $-0.071 * * *$ & -164.82 & 57.91 & $-858.85 * *$ & -483.31 & $-0.622 * * *$ \\
\hline & $(0.019)$ & $(334.0)$ & $(272.8)$ & $(353.9)$ & $(396.8)$ & $(0.158)$ \\
\hline \multirow[t]{2}{*}{ Single Mother*1991 } & -0.010 & -162.20 & 28.95 & 81.50 & $-823.96^{*}$ & -0.177 \\
\hline & $(0.025)$ & (919.5) & $(1,129.6)$ & $(533.6)$ & $(475.6)$ & $(0.210)$ \\
\hline \multirow[t]{2}{*}{ Single Mother*1993 } & 0.005 & -408.05 & -530.28 & 969.04 & -488.16 & -0.011 \\
\hline & $(0.020)$ & $(600.2)$ & $(486.3)$ & $(784.2)$ & $(454.7)$ & $(0.178)$ \\
\hline \multirow[t]{2}{*}{ Single Mother*1995 } & -0.024 & -801.03 & -186.52 & -346.76 & $-1,105.41 * *$ & $-0.298^{*}$ \\
\hline & $(0.016)$ & $(657.8)$ & (719.9) & $(477.8)$ & $(496.5)$ & $(0.151)$ \\
\hline \multirow[t]{2}{*}{ Single Mother*1996 } & -0.026 & $-2,631.25 * * *$ & $-3,132.00 * * *$ & $-2,189.69$ & $-2,193.74 * * *$ & $-0.348 * *$ \\
\hline & $(0.019)$ & $(580.9)$ & $(1,019.3)$ & $(1,326.2)$ & $(443.7)$ & $(0.168)$ \\
\hline \multirow[t]{2}{*}{ Single Mother*1997 } & -0.017 & $-1,552.47 * * *$ & $-1,589.48 * * *$ & $-788.04 *$ & $-1,927.63 * * *$ & -0.250 \\
\hline & $(0.022)$ & $(464.2)$ & $(490.4)$ & $(412.1)$ & $(449.7)$ & $(0.180)$ \\
\hline \multirow[t]{2}{*}{ Single Mother*1999 } & -0.001 & $-2,266.85^{* * *}$ & $-1,632.70 * * *$ & -527.56 & $-2,009.38 * * *$ & -0.154 \\
\hline & $(0.025)$ & $(685.1)$ & $(547.8)$ & (490.19) & $(458.5)$ & $(0.226)$ \\
\hline
\end{tabular}

Race \& Ethnicity

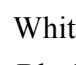

\section{Black}

$-0.130 * * *$

$(0.011)$

Amer. Ind, Esk, Aleut

$-0.101 * * *$

(0.024)

Asian or Pacific Isl.

$-0.110 * * *$

Hispanic Origin

(0.014)

$-0.134 * * *$

(0.017)

College

$$
\begin{gathered}
0.172 * * * \\
(0.006)
\end{gathered}
$$

Ages

$\begin{array}{cc}20-25 & --- \\ 25-34 & -0.033 * * * \\ & (0.007) \\ 35-44 & -0.058 * * * \\ & (0.006) \\ 45-55 & -0.082 * * * \\ & (0.006)\end{array}$

Welfare Prog Changes

Wavier Implemented

$$
\begin{gathered}
0.676 * * * \\
(0.015) \\
0.676 * * *
\end{gathered}
$$

TANF Implemented$$
(0.015)
$$

Year

$\begin{array}{cc}--- & --- \\ -1,605.22 * * * & -1,400.14 * * * \\ (202.3) & (265.5) \\ -958.22 & 905.72 \\ (1,175.4) & (2,096.8) \\ 597.30 & 1,264.024 \\ (599.0) & (936.0) \\ -1,761.94 * * * & -1,491.58 * * * \\ (197.0) & (306.2) \\ 3,244.73 * * * & 3,017.00 * * * \\ (282.7) & (386.7)\end{array}$

---
$-1,753.87 * * *$
$(251.3)$
$-1,354.17^{* *}$
$(569.8)$
$1,102.69 * *$
$(480.0)$
$-1,725.42 * * *$
$(325.0)$$$
-1,6
$$$$
-1,623.55 * * *
$$$$
\text { (115.6) }
$$$$
-1.148 * * *
$$$$
-1,907.45 * * *
$$$$
\text { (0.098) }
$$$$
\text { (423.8) }
$$$$
-0.926^{* * *}
$$$$
\text { (0.223) }
$$$$
137.25
$$$$
\text { (262.6) }
$$$$
-0.849 * * *
$$$$
-1,622.73 * * *
$$$$
\text { (0.130) }
$$$$
\text { (150.8) }
$$$$
-1.250 * * *
$$$$
\text { (0.152) }
$$$$
4,198.45 * * *
$$$$
-1.148 * * *
$$$$
\text { (91.7) }
$$$$
1.729 * * *
$$$$
\text { (0.058) }
$$

$\begin{array}{cc}--- & --- \\ -430.92 & 818.95 * * * \\ (286.8) & (288.9) \\ -1,730.32 * * * & 64.89 \\ (266.4) & (285.9) \\ -1,965.21 * * * & 227.25 \\ (367.1) & (502.5)\end{array}$

---
$-424.33^{*}$
$(217.4)$
$-882.79 * * *$
$(214.7)$
-635.33
$(626.1)$

$$
\begin{gathered}
--- \\
-786.16 * * * \\
(121.7) \\
-1,682.36 * * * \\
(126.6) \\
-1,992.04 * * *
\end{gathered}
$$$$
-0.314 * * *
$$$$
\text { (0.072) }
$$$$
-0.635 * * *
$$$$
\text { (0.061) }
$$$$
-0.878^{* * *}
$$$$
\text { (130.0) }
$$$$
\text { (0.061) }
$$

-464.41
$(372.7)$
605.54
$(952.8)$

64.36
$(277.0)$
$1,312.40$
$(1,372.2)$

(122.9)

$-0.061$

(322.8)

419.91

$(1,372.2)$

$-630.69 * * *$

(0.118)

(726.8)

(202.7)

$-0.275^{* *}$

(0.121) 


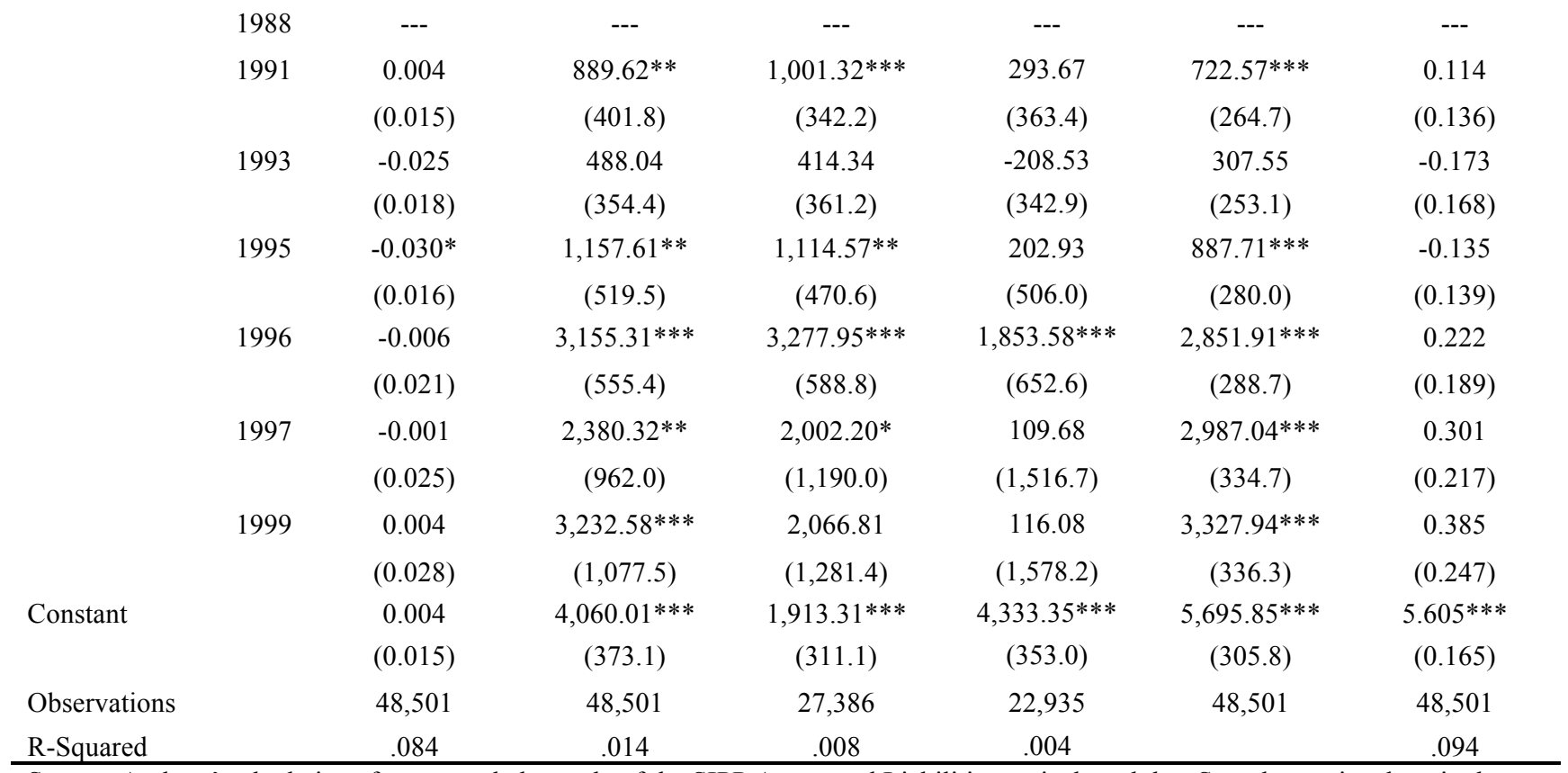

Source: Authors' calculations from a pooled sample of the SIPP Assets and Liabilities topical modules. Sample restricted to single mothers and single childless women, 19-55.

Notes: All models include region controls. Standard errors in parentheses.

$* * * \mathrm{p}<0.01, * * \mathrm{p}<0.05, * \mathrm{p}<0.1$ 
Table 4

Multivariate Results: Household Unsecured Debt of Single Mothers, Ages 19-55, 1988-1999 $(2005 \$)$

\begin{tabular}{|c|c|c|c|}
\hline & All Single Women & $\begin{array}{c}\text { Quant Reg } \\
75^{\text {th }} \text { Percentile }\end{array}$ & IHS \\
\hline Variable & $(1)$ & $(2)$ & $(3)$ \\
\hline \multirow[t]{2}{*}{2 or more children (1995) } & 180.74 & $-909.23 * * *$ & $-0.889 * * *$ \\
\hline & $(602.5)$ & $(314.1)$ & $(0.225)$ \\
\hline \multirow[t]{2}{*}{2 or more children $* 1988$} & $-1,488.69^{*}$ & 174.12 & 0.080 \\
\hline & $(810.19)$ & $(521.0)$ & $(0.378)$ \\
\hline \multirow{2}{*}{2 or more children $* 1991$} & $-1,571.84$ & 150.69 & 0.380 \\
\hline & $(1,715.5)$ & $(416.7)$ & $(0.261)$ \\
\hline \multirow[t]{2}{*}{2 or more children $* 1993$} & $-1,203.99$ & 528.01 & 0.218 \\
\hline & $(1,282.32)$ & $(392.8)$ & $(0.274)$ \\
\hline \multirow[t]{2}{*}{2 or more children $* 1996$} & $-1,648.99 * *$ & $-986.40 * * *$ & -0.108 \\
\hline & $(671.5)$ & (373.9) & $(0.293)$ \\
\hline \multirow[t]{2}{*}{2 or more children $* 1997$} & $-1,801.56^{* *}$ & $-818.77 * *$ & 0.134 \\
\hline & $(764.5)$ & $(382.7)$ & $(0.286)$ \\
\hline \multirow[t]{2}{*}{2 or more children $* 1999$} & $-1,171.20$ & $-1,468.32 * * *$ & -0.113 \\
\hline & $(846.571)$ & (397.0) & $(0.325)$ \\
\hline
\end{tabular}

Race \& Ethnicity

$\begin{array}{rccc}\text { White } & --- & -- & -- \\ \text { Black } & -1,750.73^{* * *} & -1,649.76^{* * *} & -1.408^{* * *} \\ & (233.7) & (112.2) & (0.102) \\ \text { Amer. Ind, Esk, Aleut } & 253.17 & -1,677.37^{* * *} & -1.229^{* * *} \\ & (2,821.1) & (418.4) & (0.315) \\ \text { Asian or Pacific Isl. } & -143.24 & -510.34 & -0.887 * * * \\ & (694.3) & (352.6) & (0.248) \\ \text { Hispanic Origin } & -1,415.52^{* * *} & -1,248.49^{* * *} & -1.358^{* * *} \\ & (376.3) & (146.7) & (0.167) \\ & 3,011.98^{* * *} & 3,773.76^{* * *} & 1.932^{* * *} \\ & (247.0) & (101.9) & (0.127)\end{array}$

Ages

$\begin{array}{cccc}20-25 & --- & --- & -- \\ 25-34 & 350.03 & -207.21 & 0.002 \\ & (226.5) & (148.9) & (0.114) \\ 35-44 & 187.39 & -105.19 & 0.209^{*} \\ & (239.6) & (149.9) & (0.111) \\ 45-55 & 812.20 & 352.81^{*} & 0.130 \\ & (775.9) & (191.09) & (0.153)\end{array}$

Welfare Prog Changes

Wavier Implemented

$-615.59$

87.40

0.075

(493.5)

(134.23)

$(0.140)$

TANF Implemented

54.12

$-250.30$

$-0.214$

(351.9)

(212.20)

(0.157) 
Year

\begin{tabular}{lcccc} 
& 1988 & 266.48 & 32.71 & $0.410^{*}$ \\
& $(652.4)$ & $(361.6)$ & $(0.240)$ \\
& 1991 & $1,145.45$ & 120.68 & 0.259 \\
& $(1,689.3)$ & $(298.1)$ & $(0.241)$ \\
& 1993 & 320.65 & -310.48 & 0.154 \\
& $(720.0)$ & $(276.1)$ & $(0.184)$ \\
& 1995 & --- & & \\
& 1996 & $1,225.52^{* *}$ & $1,071.68^{* * *}$ & 0.252 \\
& & $(460.5)$ & $(294.2)$ & $(0.193)$ \\
Constant & 1997 & $1,689.85^{* *}$ & $1,277.92^{* * *}$ & 0.265 \\
& & $(655.0)$ & $(345.9)$ & $(0.245)$ \\
Observations & 1999 & $1,479.24 * *$ & $1,953.59^{* * *}$ & $0.548^{* *}$ \\
R-Squared & & $(571.8)$ & $(353.6)$ & $(0.225)$ \\
\hline Soure:Aut Aut & $3,010.28^{* * *}$ & $3,743.33^{* * *}$ & $4.432^{* * *}$ \\
& & $(431.7)$ & $(356.6)$ & $(0.181)$ \\
& & 16,209 & 16,209 & 16,209 \\
& & 0.014 & & 0.104 \\
\hline
\end{tabular}

Source: Authors' calculations from a pooled sample of the SIPP Assets and Liabilities topical modules. Sample restricted to single mothers and single childless women, 19-55.

Notes: All models include region controls. Standard errors in parentheses.

$* * * \mathrm{p}<0.01, * * \mathrm{p}<0.05,{ }^{*} \mathrm{p}<0.1$

Table A. 1

IHS Models: Calculated Average Values of Real Unsecured Debt and IHS Estimates All single women

\begin{tabular}{lcccc} 
& $($ Mean $)$ & IHS estimates & IHS D-D derivatives & IHS derivatives \\
\hline & $(1)$ & $(2)$ & $(3)$ & $(4)$ \\
\hline & & & & All single \\
Single Mother*1988 & 4157.331 & $-0.622^{* * *}$ & -2585.17 & -2585.17 \\
Single Mother*1991 & 4713.052 & -0.177 & -835.87 & -3421.04 \\
Single Mother*1993 & 4308.869 & -0.011 & -49.00 & -2634.17 \\
Single Mother*1995 & 4613.058 & $-0.298^{*}$ & -1373.99 & -3959.17 \\
Single Mother*1996 & 6346.763 & $-0.348^{* *}$ & -2210.66 & -4795.84 \\
Single Mother*1997 & 6009.752 & -0.250 & -1504.39 & -4089.57 \\
Single Mother*1999 & 6637.712 & -0.154 & -1021.86 & -3607.03 \\
& & & & \\
& Single mothers & IHS estimates & IHS D-D derives & IHS derivatives \\
& & & Single mothers & Single mothers \\
2 more children*1995 & 3046.075 & $-0.889 * * *$ & -2707.77 & -2707.77 \\
2 more children*1988 & 3091.214 & 0.080 & 246.92 & -2460.85 \\
2 more children*1991 & 3093.679 & 0.380 & 1177.08 & -1530.69 \\
2 more children*1993 & 3221.334 & 0.218 & 703.82 & -2003.95 \\
2 more children*1996 & 3788.506 & -0.108 & -407.86 & -3115.63
\end{tabular}


Source: Authors' calculations from a pooled sample of the SIPP Assets and Liabilities topical modules. Sample restricted to single mothers and single childless women, 19-55.

Notes: IHS D-D estimates are calculated using $\partial \mathrm{y} / \partial x=\sqrt{y^{2}+1} * \hat{\beta}$, where, $\mathrm{y}$ is the real values of unsecured debt and $\mathrm{x}$ is independent variable. All models include region controls. Standard errors in parentheses.

$* * * \mathrm{p}<0.01, * * \mathrm{p}<0.05, * \mathrm{p}<0.1$

\section{References}

Barrow, L. and L.McGranahan. (2000). The effects of the Earned Income Credit on the seasonality of household expenditures. National Tax Journal, 53(4), 1211-1244.

Bumpass, L.L. \& Raley, R.K. (1995). Redefining single-parent families: Cohabitation and changing family reality. Demography, 32 (1995), 97-109.

Burbidge, J.B., Magee, L., \& Robb, A.L. (1988). Alternative transformations to handle extreme values of the dependent variable. Journal of the American Statistical Association, 83(401), 123-127.

Currie, J. (2006). The take-up of social benefits. In A. Auerbach, D. Card \& J. Quigley (Eds.) Poverty, the distribution of income, and public policy. New York: Russell Sage Foundation, 80-148.

Crouse, Gilbert. 1999. "State Implementation of Major Changes to Welfare Policies, 1992-1998." Available at aspe.hhs.gov/hsp/Waiver-Policies99/policy_CEA.htm. Access date February 8, 2010.

Czajka, J. L., Jacobson, J. E., \& Cody, S. (2003). Survey Estimates of Wealth: A Comparative Analysis and Review of the Survey of Income and Program Participation. Washington, DC: Mathematica Policy Research. Available at www.ssa.gov/policy/docs/contractreports/SurveyEstimatesWealth.pdf. Accessed April 12, 2010.

Dahl, M., DeLeire, T., Schwabish, J. (2009). Stepping stone or dead end? The effect of the EITC on earnings growth. National Tax Journal, 62(2), 329-46.

Garcia, J.A. (2007). Borrowing to make ends meet: The rapid growth of credit card debt in America. A report by Demos: A network for ideas \& action. Available at www.demos.org/pubs/stillborrowing.pdf. Access date: April 12, 2010.

Eissa, N. \& Liebman, J.B. (1996). Labor supply response to the Earned Income Tax Credit. Quarterly journal of economics, May, 605-637.

Ellwood, D.T. (2000). The impact of the Earned Income Tax Credit and social policy reforms on work, marriage, and living arrangements. National tax journal, 53(4, 2), 1063-1105.

Folk, F.K. (1996). Single mothers in various living arrangements: Differences in Economic and time resources. The American Journal of Economics and Sociology, 55(3), 277-92.

Hotz, V.J. \& Scholz, J.K. (2003). The earned income tax credit. In R. Moffitt (ed.) Means-tested transfer programs in the U.S. Chicago: University of Chicago Press, pp. 141-98

Hoynes, H. (2008). The earned income tax credit, welfare reform, and the employment of low-skilled single mothers. Paper prepared for Chicago Federal Research Bank of Chicago Conference "Strategies for improving economic mobility of workers," November 2007. 
Mendenhall, R., Edin, K., Crowley, S., Sykes, J., Tach, L., Kriz, K. \& Kling, J. (2010). The Role Earned Income Tax Credit in the Budgets of Low-income Families. National Poverty Center Working Paper \#10-05, http://npc.umich.edu/publications/u/working paper10-05.pdf.

Meyer, B.D., \& Rosenbaum, D.T. (2001). Welfare, the Earned Income Tax Credit, and the Labor Supply of Single Mothers. Quarterly Journal of Economics 116 (3), 1063- 1114.

Meyer, B.D. \& Sullivan, J.X. (2004). The effects of welfare and tax reform: The material well-being of single mothers in the 1980s and 1990s. Journal of public economics, 88(2004), 1387-1420.

National Research Council, (1995). Measuring poverty: A new approach. National Academy Press.

Ratcliffe, C., Chen, H., Williams Shanks, T. R., Nam, Y., Schreiner, M., Zhan, M., et al. (2008). Assessing Asset Data. In S. McKernan \& M. Sherraden (Eds.), Asset Building and Low-Income Families. Washington, DC: Urban Institute Press.

Rhine, S. L. W., S. Su, Y. Osaki, and S. Y. Lee. (2005). Householder Response to the Earned Income Tax Credit: Path of Sustenance or Road to Asset Building. Working Paper, Office of Regional and Community Affairs, Federal Reserve Bank of New York, and Community Food Resource Center, NY. Available at www.assetbuilding.org/AssetBuilding/Download Docs/Doc File 1238 1.pdf. Access date: April 12, 2010.

Romich, J. and T. Weisner. (2000). How families view and use the EITC: Advance payment versus lump sum delivery. National tax journal, 53(4), 1245-64.

Smeeding, T.M., Phillips, K.R., \& O’Conner, M. (2000). The EITC: Expectation, knowledge, use, and economic and social mobility. National tax journal, 53(4), 1187-1210.

Scholz, J.K. (1994). The Earned Income Tax Credit: Participation, compliance, and anti-poverty effectiveness. National tax journal, 47(March), 59-81.

Spader, J., J. Ratcliffe, and M. A. Stegman. (2005). Transforming Tax Refunds into Assets: A Panel Survey of VITA Clients in Greenville, Henderson, and Raleigh, North Carolina. Center for Community Capitalism, University of North Carolina at Chapel Hill. Available at www.kenanflagler.unc.edu/assets/documents/ccTransformingTaxRefunds.pdf. Access date: April 12, 2010.

Sullivan, J.X. (2006). Welfare reform, saving, and vehicle ownership for the poor: Do asset tests and vehicle exemptions matter? Journal of human resources, 41(1), 72-105.

Sullivan, J.X. (2008). Borrowing during unemployment: Unsecured debt as a safety net, Journal of human resources, 43(2), 383-412.

Tax Policy Center (2010). Historical EITC parameters. Available at www.taxpolicycenter.org/taxfacts/displayafact.cfm?Docid=36. Access date: November 10, 2009. 